\title{
Persuasion Strategies on Instagram in Wine Communication and Branding
}

\author{
Ágnes VESZELSZKI \\ Corvinus University of Budapest, Hungary \\ e-mail: agnes.veszelszki@uni-corvinus.hu
}

\begin{abstract}
Objectives: On social media, or in the world of the so-called like economy, highly targeted advertising has become reality: whereas previously advertisers only suspected the whereabouts of their customers, now they know it exactly based on well-defined parameters. Likes have become a new standard of value. With the increased popularity of Like buttons, influencer marketing and content marketing have also gained in importance. This paper aims to explore the persuasion strategies used by visual content marketing as a tool of visual rhetoric. Methodology: After reviewing the relevant literature, the paper presents a case study from the field of wine communication: using the methodology of content analysis and a qualitative approach, it examines the visual and verbal characteristics of 100 Instagram posts of Hungarian wineries. The examination focused on content from a semiotic aspect, complementary verbal elements (captions, hashtags), the assumed intention of content marketing, and the characteristics of visual storytelling. Findings: Although wine communication is very much about creating a personal feeling, there was not a single person on 61 of the 100 examined Instagram photos. The potential of branded hashtags is exploited by almost every winery in their communication. The most dominant content types were the informative, aesthetically pleasing, and explicit advertising content. Suggestions: To obtain the loyalty of users, companies need a wellconsidered communication strategy tailored to the target audience. The most relevant social media principles are the following: long-term strategy, careful planning, conscious implementation, thorough information about and respect for the potential target audience, and content which is valuable and interesting for the target group and has real impact on its behaviour. It could also enhance user loyalty if posts had more added value. The methodology of storytelling could be exploited in wine communication for the following types of content: 1 . advice and education: providing background knowledge (winemaking, viticulture, design, wine-food pairing) or instructions ("how to" videos e.g. on bottle opening); 2 . help to users (information on moderate wine consumption, wine and a healthy lifestyle); 3. entertainment (people behind the bottle, family and historical stories, wine legends, anecdotes). In addition, creating a personal feeling is crucial in wine communication,
\end{abstract}


which is specializing in handling uncertainty: winemakers can act as influencers in their field not only when selling wine but also in social media marketing.

Keywords: visual rhetoric, content marketing, social media, Instagram

\section{Objectives of the Study}

Social media has significantly reshaped not only social interactions but also organizational and marketing communication. The so-called like economy (Gerlitz-Helmond, 2013; Veszelszki, 2018d) is determined by the social buttons (including Facebook's like and other reaction buttons and Instagram's heart icon). Based on an analysis of wine communication on Instagram (cf. Veszelszki (ed.), 2018), this paper examines the persuasion strategies used by visual content marketing as a tool of visual rhetoric. The paper also discusses verbal-visual relations and the relationship between photos and hashtags.

\section{Basic Concepts}

\section{Like Economy and Content Marketing}

Web 2.0 is the version of the web that is based on participation and cooperation (Beer, 2009: 985); it differs from Web 1.0 technologically, structurally, and socially: "the former object-oriented approach is replaced by a more individualoriented network" (Peters, 2009: 15), and it is characterized by the "growth of social networks, bi-directional communication, (...) and significant diversity in content types" (Cormode-Krishnamurthy, 2008). The essence of Web 2.0 is interactivity: these online services are based on community where participants produce and assess all the content (user-generated content, UGC; Beer, 2009: 986; Jenkins et al., 2006).

Social media, as a key Web 2.0 phenomenon, has also substantially changed organizational and marketing communication. In the early days of Internet marketing, in the age of the "hit economy", information was linked through hits. Every hit and click represented a visitor of a website, and revenue was generated through banners (Van Pappelendam, 2012; Gerlitz-Helmond, 2013). According to Gerlitz and Helmond, the second great era was the "link economy", where the quality and quantity of links were weighed (Gerlitz-Helmond, 2013: 1351). The current third era, the "like economy", is determined by social buttons. Many of them can be found on plenty of websites, but the most famous one is the "Like" button introduced by Facebook in 2009, depicting a hand giving the "thumbs up" 
associated with the word "like". Its counterpart on Instagram is the "Heart" icon, which is also used to express liking.

In social media, which is based on user participation and collaboration, liking (such as sharing) is a predefined communication act as opposed to making comments where users may express themselves more freely. According to Anne Helmond and Carolin Gerlitz, the authors of The Like Economy (2013), "The Like is always a collective. It is more than +1 ." And why are likes important from an economic and communication perspective? Because they "allow the instant transformation of user engagement into numbers on button counters, which can be traded and multiplied but also function as tracking devices" (GerlitzHelmond, 2013). Emotion-based relationships can be manifested in several ways (Arvidsson, 2011), including hitting the Like button. In like economy, "the social is of particular economic value, as user interactions are instantly transformed into comparable forms of data and presented to other users in a way that generates more traffic and engagement" (Gerlitz-Helmond 2013: 1349). In a culture based on recommendations and likes, users' interactions with each other and with contents are recorded in databases.

In a "recommendation culture", not only global large and medium-sized enterprises can make their way but also smaller ones (cf. boyd, 2010). At the start, every new user of Facebook and Instagram (which is also owned by Facebook) enjoys equal opportunities: they have the same default profile settings to customize to their needs. Naturally, however, there are vast differences between the human and financial resources available for a sole trader and a multinational company for editing such profiles. The role of paid ads has significantly increased since Facebook and Instagram started to continuously decrease organic reach to push profile managers towards buying paid and targeted advertising. Compared to the production and marketing costs of outdoor or television ads, advertising on these websites is one of the most cost-effective and efficient ways of reaching the target audience, due targeting and customization.

The competitive advantage of Facebook and Instagram comes from customized ads. The two interconnected social networking websites have a detailed insight into the demographic, computer and mobile usage, information-seeking behaviour, and even buying habits of more than two billion users, which can be used for serving advertisers. Users are providing "endless and virtually unlimited information about their everyday lives" (both intentionally and unintentionally) (Beer, 2009: 997). Highly targeted advertising has become reality: whereas previously advertisers only suspected the whereabouts of their customers (based on events, websites etc.), now they know it exactly based on well-defined parameters (targeted micromarketing; cf. Hendricks-Vestergaard, 2019). This leads us to the topic of Web 3.0 or the semantic web: the world of personalized services and, of course, advertisements. Precise information about the customers 
also enables remarketing, that is, the repeated addressing of previously engaged customers.

Facebook, Instagram, and social media in general are apparently innovating the toolset of a centuries-old marketing technique: content marketing. The essence of content marketing is to "influence a target group's behaviour by sharing useful (valuable and relevant) content with them, made specifically for them, to the benefit of all parties involved" (W1, W2). This can be done with the purpose to provide assistance (answer questions, help making decisions, give advice), to improve users' lives, or to entertain. Content marketing is successful if it manages to make profit and produce measurable, quantifiable results by sharing useful content.

Micro-celebrities, or "Insta-celebs", with many followers on social media also act as opinion leaders (cf. Marwick-boyd 2010; Senft, 2008), which can be quite profitable for them: marketing teams contact online opinion leaders increasingly often requesting them to make subtle hints at or express reference to a product or service in consideration of financial support or certain products (or product samples). This technique is called influencer marketing. Influencers have the ability to create a special relationship with their audience, what brands could never achieve through traditional advertising tools. Their reach can be small, limited to a tight-knit community (micro-influencers), or global (celebrities) (Pellicer, 2018). "Intimacy and authenticity, or at least the impression of it, are often the key to success on Instagram" (Simon, 2019). Influencers interact with their followers as if they were good friends: sharing personal moments with their fans and allowing them to "look behind the scenes" - or at least are left in the belief that this is what they get to see. According to Alice Marwick (2015), influencers use "strategic intimacy" to appeal to followers and thus gain more popularity.

Facebook and Instagram provide new opportunities for organic marketing, which, in essence, means that companies share valuable content to improve brand transparency and visibility, and their representatives take part in the (online) dialogue enabling consumers to create a personal commitment towards the brand (company, organization, or person).

Note, however, that the Like button does not give superpowers to marketing. A like or an Instagram heart is not a signed contract or an actual sale. Even if users become active followers of a company's page where they find the content valuable or interesting, this is no guarantee that they will buy any product from the company. Howell (2013) explains that "customer engagement with a brand on social media does not at all mean customer loyalty to the brand: the engagement can have various other purposes". There are certain product groups (e.g. fashion, cosmetics, gastronomy, travelling) with which users identify themselves more easily. In a social media context, a brand can be so attractive that people will do everything to engage with it as it gives them the feeling of style (TurnerShah, 2010: 21; Howell, 2013). Obviously, consumers will follow products and 
brands that match their self-image (Kemp et al., 2012: 509). But the number of fans, however high, is no guarantee for business success: quantity does not equal quality. It is better to obtain and retain fewer active (participating, sharing) fans than many followers who later disappear. Some studies question the value of likes: apparently, real participation, such as writing comments, is more important than likes as it signals greater commitment (Crosby, 2017). In addition, the rule of patience should also be borne in mind: social media marketing produces results only in the long run (as the popular advice goes: it is more like a marathon than a sprint; W3).

\section{Visual Communication - Visual Storytelling}

One of the most important tools of social media marketing reviewed so far is visuality. With technological development, visual communication is becoming part of our everyday lives, and the already vast number of images shared online is continuously increasing (Giulani, 2006: 185); in fact, some already talk about the omnipresence of images (Maar, 2006). Images can be understood without knowledge of the cultural context or the language, and they can depict even complex processes in a simple form (Maar, 2006: 11-14). As opposed to verbal language with its conventionalized symbols permitting only linear decoding, visual language can be decoded quickly and simply. Images are not under the control of the mind; with their suggestive power, they can directly influence our thoughts and feelings (Giulani, 2006: 185).

The simplification of producing, editing, and distributing digital pictures has also changed the role of pictures. In marketing, pictures were traditionally treated as illustrations to texts or as a kind of decoration which represents an ideal world. However, today's fierce fight for consumers' attention requires new types of visual content. The so-called storytelling pictures (including graphics, photos, and videos) build on the visual narrative. This shift of perspective is reflected in the collections of stock photo agencies, which used to prefer standard, neutral and - therefore - widely usable pictures. Today, however, there are swipe-stopping images which look realistic and authentic (which explains the growing share of photobloggers' and amateur photographers' works in stock photos). In addition, a "good" picture catches the eye, it is easily remembered, emotionally touching, more than the optical repetition of the text, and reflects something more than what is evident; in other words: it tells a story (cf. Baldoni, 2011; Veszelszki, 2018e).

When designing visual storytelling, you have to keep in mind how pictures create their impact. From the perspective of telling narratives, there are three types of images: impulsive, experience-based, and culture-specific pictures. Impulsive pictures provoke predictable reactions (such as smiling or an urge of caring). The latter forms the basis of photos of charming, likeable cartoon characters, cute 
small children with a tiny nose and big eyes, which activate the instinct of caring for vulnerable beings and trigger emotional reactions in the viewer. Experiencebased pictures also arouse emotions (e.g. childhood photos, wedding photos, or photos of the 9/11 attacks). Emotions play an important role in memory. This was evidenced by Larry Cahill and others (1996) in an experiment where they monitored the brain activity of subjects viewing 12 emotionally neutral and 12 emotionally arousing film clips. Three weeks later the subjects were asked to recall what they saw. The result is not surprising: the more emotional the film clip was, the better the subjects recalled them. In another experiment, Kelsey Libert and Kristin Tynski (2013) showed subjects pictures which had gone viral on the image-sharing website Imgur and asked them about the emotions provoked (the control group was shown "non-viral" pictures that were shared only a few times). It turned out that the images playing on positive emotions (pleasure, excitement, trust) were more successful than those playing on negative emotions (except if they surprised the viewers by going against viewers' expectations). The third category comprises culture-specific images. We can think of the emotional effect of colours or the use of different motives. It is almost impossible to look at these pictures without emotions.

So, how could we define the concept of visual storytelling? It is the telling of stories in a visual format (image, video, infographic, presentation, meme, or other format based on visuality) through the mass media (typically in social media but also in print media) primarily in a way that triggers emotional reactions. It often serves marketing purposes, in which case the visual story is built around a brand and the related offers (cf. Walter-Gioglio, 2015). As opposed to advertisements based on generalities, the speciality - and also difficulty - of storytelling marketing is that it focuses on a single specific example (so, it should be carefully selected) and appeals to emotions instead of reason.

In a broader context, new technology - especially the smartphone - allows us to produce a narrative of our lives: to choose what to remember and what to contribute to our own mythos through recorded and shared content (cf. Renner, 2019). Note, however, that images are not necessarily shared to promote remembering but much more for the sake of sharing experiences (Jurgenson, 2019). This trend is reinforced by "ephemeral" or disappearing content such as Snapchat messages or Instagram Stories images and videos. Both the documentation and the sharing of experiences function of image sharing can be exploited for marketing purposes, and both can be implemented through visual storytelling.

Therefore, this toolset should be looked more closely. An impressive story, whether visual or verbal, uses the following five building blocks (cf. Bergström, 2008; Gallo, 2016): 1. Hero: the story must have a character with imperfections who the audience can identify with. 2. Conflict: if the outcome corresponds to what is expected, the story is boring and banal (e.g. a diligent student from 
a decent and supportive background becomes a successful adult); however, if the outcome is achieved through struggles and difficulties, the story becomes exciting (e.g. a poor individual works hard and becomes rich; the hero fights for love; the powerless overcomes the powerful). 3. Impulsivity: as mentioned before, the story will have a lasting effect if it can provoke (positive or negative) emotions from the audience. 4. Potential virality: the story is simple enough to be remembered but interesting enough to be shared with others. 5. Meaningful essence: the core message, the purpose, the intended effect of the story should be clear (e.g. a joke exerts its effect through the punch line, a moral story through the lesson). In particular, narrative images have the following criteria: 1. authenticity; 2. uniqueness (i.e. focus on special moments instead of stereotypical situations); 3. engagement of various senses; 4. use of archetypes (common patterns, roles) such as the warrior, the healer, the seducer, the magician, the protector, etc.; cf. Sammer-Heppel 2015).

\section{Wine Communication}

I have chosen wine communication (Veszelszki (ed.), 2018) to illustrate how visual storytelling works. This practical research area covers the entirety of wine culture and wine business: the cultural and literary history of wine as a special product (Balázs, 2018a, b; Magyari, 2018; Pál, 2018), wine and sacrality (Kovács, 2018), the role of wine in Hungarian culture (Szakáli, 2018; Benyák, 2018; Gyanó, 2018), wine production (Szappanos, 2018), wine marketing (Hofmeister-Tóth, 2018; Kovács, 2018; Ipacs, 2018; Orbán, 2018; Balogh, 2018), wine journalism (Németh, 2018), and the communication-related characteristics of wine consumption (Veszelszki, 2018a, 2019 [i.p.]; Lakits et al., 2018). The topic may also include the history of wine philosophy (cf. Allhoff ed., 2008), the communication aspects of wine rating systems, wine talk, or "oinoglossia" (Lehrer, 2009; Veszelszki, 2018b, c), and so on.

As the rating and description of wines are strongly influenced by preferences, wine communication is clearly defined by values (Veszelszki, 2019 [i.p.]). In addition, "in the case of wines, quality can only be assessed after consumption, which makes them high-risk products” (Kovács, 2018: 125; Sherman-Tuten, 2011: 222-223). This is why wine is a good choice for examination from a marketing and visual communication perspective. 


\section{Wine Communication on Instagram: Persuasion Strategies}

\section{Wine Communication and Storytelling}

In any sales activity, it is essential that the seller is never in doubt about the product; they must passionately, without reservations, believe in the product they want to sell. It is a special characteristic of wine marketing, however, that the seller always specializes in uncertainty. This means two things: on the one hand, the actual quality can only be checked when the bottle is opened (revealing any wine fault such as "cork taint"); on the other hand, the vast majority of wine consumers are laypeople, which implies that the wine seller is in a dominant position, while the wine consumer is in a defensive position from an information perspective. This ambiguity can be exploited, ${ }^{1}$ but consumer uncertainty can be also reduced, if necessary, by communication techniques (e.g. through relatively constant brand communication, positioning the product range, etc.). The key role of price-perceived quality heuristics is another special feature: in the wine market, a high price is clearly taken as proof of high quality/value. Most wine-conscious customers will not be looking for the cheapest product as wine is usually a prestige product, whether purchased for consumption or as a gift.The creation of a personal feeling is key in wine marketing and wine-related storytelling. ${ }^{2}$ First, you have to "sell" the winemaker, who makes the wine authentic, and only then the product. In a conscious wine marketing strategy, therefore, the first story is about the uniqueness or special struggles of the winemaker, ${ }^{3}$ and the second story can be adapted to the wine product. $^{4}$

The five main steps of establishing the story of a winery are as follows (cf. Maker, 2015):

1. Identification. During this process, the winery has to consider the origins, history, and ethos ("Why the winery was established? And how? What makes it special?”). This helps to clarify the core brand attributes, which can serve as a starting point for (content) marketing. ${ }^{5}$

1 Unless you are an expert in wine, could you or would you dare to say that a 1,000-dollar bottle of 1982 Château Margaux contains not the original drink but a 90-dollar cheap wine?

2 It is no coincidence that the Hungarian Tourism Agency built the brand concept of Hungarian wine around the motto Hungarian wine - personal touch in the spring of 2019 (W4).

3 Remarkable Hungarian examples include the story of György Lőrincz, owner of St. Andrea Winery (cf. Lajos Kovács, 2018), the story of the young generations of multi-generational family wineries, or the joint efforts of successful female winemakers (Szabó (ed.), 2017).

4 For example, how mineral soil influences wine or how a nearly extinct ancient grape variety was saved and revived (e.g. bakator; cf. Balázs, 2018a).

5 If, for example, the product is better consumed with food than alone ("food-friendly wine"), content marketing can focus on posting wine and food pairings on social media such as Pinterest (which enables saving recipes). 
2. Differentiation. Marketing is all about finding the distinctive features: winemakers have to find out how the brand attributes identified in the previous step differ from that of competing brands and have to focus marketing on such differences. ${ }^{6}$

3. Storytelling. First, winemakers have to think through how the brand relates to the three basic narratives (1. Who are we? 2. What have we learned? Why do we change? 3. How do we see the world differently?). The hero of the story will be the brand (or perhaps the winemaker), who had to overcome many difficulties (conflicts, struggle, loss, success, change) to reach the goal. A good story is always driven by sudden turns and conflicts which are resolved at the end. So, the following questions must be addressed: Who will be the hero of the story? What does he/she want to achieve? What is in the way? How can he/she overcome the conflict/difficulty?

4. Own voice. To make communication with the customers personal and conversation-like, the brand must have its own voice. For this, the winemakers have to impersonate the brand, figure out what and how it should and should never talk about, etc. ${ }^{7}$

5. Continuous updates. Constancy is important, partly because it helps committed fans to find out where, how, and in what form they can buy the wine; but equally important are innovation and renewal in communication. (In order to make successful changes in brand communication without alienating important customers, prior targeted research should be performed.)

\section{Visual Content - Visual Storytelling}

Although the Instagram app is also available from desktop computers, it is primarily intended and optimized for mobile devices, which clearly determines the user experience. Visual storytelling, thus, can be achieved in two ways on Instagram. On the one hand, narratives can be created as separate contents (a separate image or video or a series of up to ten elements). On the other hand, the Instagram interface (where visual content is displayed horizontally in threes or can be scrolled vertically) also makes it possible for the user to customize the entire profile into an own story. It is a sign of conscious profile planning if visual content is arranged in a pattern on the page (e.g. square, diagonal, tiles, rows, rainbow pattern, various frames; W3, Image 1). No matter how eye-catching the

$6 \quad$ Maker's example (2015): Stacy's wanted to reposition its crisps brand by replacing its banal motto "naturally light" to something new. It turned out that it takes 14 hours to produce a single crisp, which gave the idea for the new motto: "the hard way, the better way, the Stacy's way", which became a real success.

7 For example: how the brand would say hello, say thank you, would it use the T-form or the V-form (language-specific)? 
layout, however, it may be completely useless if the business profile owner fails to observe the basic rules of (wine) marketing.

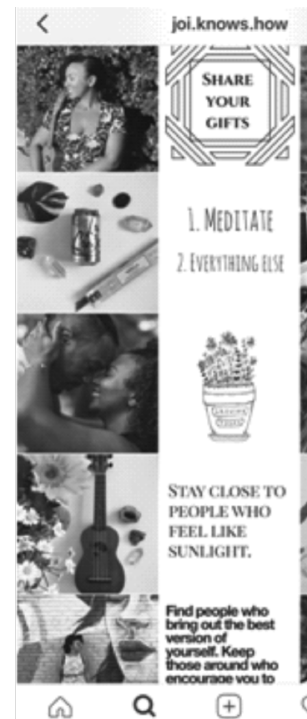

$\oplus$
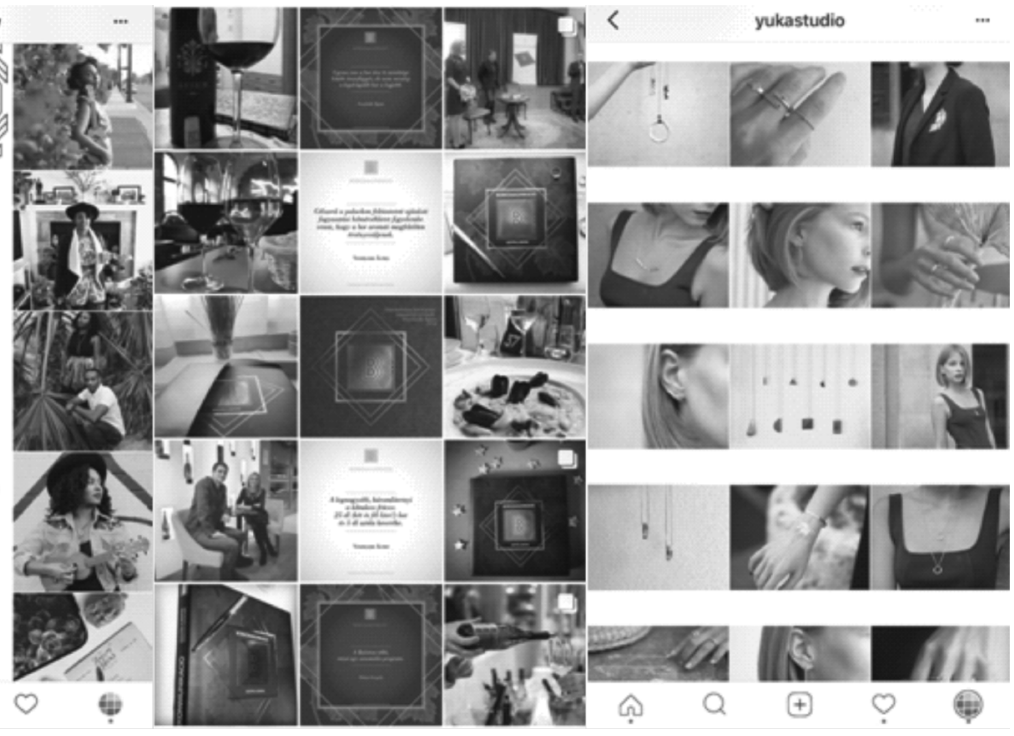

Source: Instagram

Figure 1. Conscious arrangement of Instagram profiles

\section{Image and Text: Caption and Hashtag}

On Instagram, visual content can be linked to text in several ways: captions can appear on the image itself (this is typical of stories), as accompanying text, or as hashtag. The latter has become a characteristic text type on Instagram.

Hashtag is a type of label or metadata tag primarily associated with several social networking and micro-blogging websites (Veszelszki, 2016). Searching on a hashtag will list all content with the given hashtag on the social networking website. With this sorting and searching function, however, hashtags not only connect contents, thematic blocs but also users having similar fields of interests, which make them an effective means for social movements. ${ }^{8}$ In addition to its basic functions, the hashtag is also used to abbreviate messages and to add some stylistic touch to what is being said.

Hashtags can be classified into three main types (Csire, 2015; Veszelszki, 2016). 1. Like-hunter tags are added to images to boost the number of views (e.g.: \#followme, \#likeforlike; \#instadaily, \#picoftheday). They do not form an integral part of the image; their only aim is to obtain new likes and followers. 2. Thematizing tags

8 This happened in the case of the various social media challenges such as the \#icebucketchallenge or the \#metoo campaign. 
include wide categories and usually relate to the topic of the photo (persons: \#girls, \#sommelier; objects: \#wine, \#wineglasses; events: \#wedding, \#winefestival), the manner in which the photo was taken (black and white, no filter [\#nofilter]), the mood of the photo (\#romantic, \#friendshipgoals), etc., this way making it easier to find similar content. 3. Contextualizing tags complete posts with the user's emotions, mood, or the circumstance of taking the photo. Such hashtags are much more characterized by uniqueness: they do not want to enhance searchability but to add extra verbal information to the visual content.

As regards its position, the tag can occur anywhere in a text though prototypically it takes place at the end of the text. Using multiple hashtags in the middle of the text makes comprehension quite difficult.

Marketing has also discovered the power of hashtags: they can channel visual content to more users, they can drive campaigns, and they can be used to measure the success of promotions on social media. For marketing purposes, a hashtag must be: unique, suitable for the campaign goals, distinctive, easy to remember but not too general, short but meaningful, and not too abstract (Cohen, 2015). It should be ensured that there is only one way to spell out the hashtag ("if a hashtag can be misunderstood, it will be misunderstood"; Slegg, 2014), ${ }^{9}$ and it is also recommended to check whether the tag has been used for other purposes earlier:

\section{Case Study: Hungarian Wineries on Instagram}

The exploratory study examined one hundred photos posted on Instagram. The selection criteria were as follows: for the sake of comparability, the snowball sampling method was employed to select 10 Hungarian wineries which had posted at least 10 photos on their Instagram feed and had at least 100 followers. The sample excluded the profiles of restaurants, wine distributors, wine enthusiasts, wine experts, etc. The analysis took into account the number of posted photos, the number of followers, posting frequency, the semiotic characteristics of the photos as well as the captions and hashtags added to the images. The figures reflect the situation on 20 June 2019.

The content analysis aimed to better understand what types of visual content (photos and videos) have become successful in Hungarian Instagram communication. ${ }^{10}$ For the purposes of the analysis, success was measured by the number of likes (photos) and views (videos), being aware of the contradiction

$9 \quad$ For example: \#SusanAlbumParty vs \#SusAnalBumParty.

10 It is beyond the scope of this study, but, according to my unrecorded observations over nearly three years, international wine communication on Instagram is much more conscious and strategic and much less intuitive than the Instagram usage of Hungarian wine industry stakeholders. The reason is probably the late adoption of Instagram as a marketing tool in Hungary. 
that such numbers can be influenced by several factors (e.g. whether the post was paid for, when the post was made, etc.). The posts were analysed from the following aspects: 1 . What is the image/video about and who are the characters (persons, wine, grapes etc.)? How strong is the presence of the winemaker? How evidently is the winemaker presented as an influencer? 2. How long are the texts and hashtags added to the photos, and what are they about? 3. Is there any trace of content marketing in the post (intention to help/educate; improve users' lives or environment; entertain)? 4. Does the image have any of the main characteristics of visual or verbal storytelling (eye-catching, easy-to-remember, emotionally touching image that is more than the optical repetition of the text and reflects something more than what is evident)? As the analysis advanced, the previously determined codes were complemented and reviewed. The categories of the content analysis were verified by an assistant encoder.

Table 1. The quantitative characteristics of the corpus

\begin{tabular}{lccc}
\hline & Average & Minimum & Maximum \\
\hline Followers & $4,265.5$ & 198 & 14,200 \\
\hline Image likes & 157.0568 & 15 & 1,234 \\
\hline Comment likes & 0.931818 & 0 & 10 \\
\hline
\end{tabular}

\section{Image Content}

The personal feeling is critical in wine sales. For this reason, the analysis examined how often and in what role characters appear in wine marketing photos. Of the 100 Instagram photos in the sample, 61 had no characters, 21 had only one character, 4 had two characters, and 14 had more than two characters (e.g. in a wine festival context). Of the 39 photos that included people, the characters are women on 12 , men on 16, and uncertain on 11 pictures. Six winemakers appear on altogether 17 photos. This is a very low number compared to the basic advice in wine marketing that the winemaker should be part of the sales activity. The analysis also looked at the distribution of wine types (wine appears on 44 pictures: white on 18 , red on 13, rose on 7 , and mixed arrangement on 6 photos) and presentation (in bottle on 35 , in glass on $20,{ }^{11}$ and next to food on 10 photos). Most of the photos were taken at an event (e.g. wine festival, wine awards ceremony, restaurant opening -23 in total), many others in the vineyard (16) or wine house/restaurant (14), and only a few in the wine cellar (2).

11 Sometimes both bottle and glasses appear in the picture. 


\section{Captions}

Captions are largely in Hungarian (Example 1), less often in a foreign language (Example 2) or in both Hungarian and English (Example 3). Hashtags are often in English even for Hungarian captions (Example 1).

(1) A balatoni nyári életérzés egy palackban, a mi értelmezésünkben. Egy könnyed, frissítően gyümölcsös és roppanós Olaszrizling. A halványsárga színhez barack és tavaszi fehér virágok illata társul, kóstoláskor akácvirág és barack aromák bújnak elő. „A korábbi évjáratokhoz képest 2018-ban korábban szüreteltük az alapanyagot. Végül három különböző balatoni Olaszrizling házasításából született meg a tétel, ami gyümölcsösségével, és a korai szüretnek köszönhető vibráló savaival minden nyári este tökéletes kiegészítője lehet. Nálam mindig lapul egy a hútőben!” - meséli Zsófi. » Kóstold meg te is a Laposa BalatonBor 2018-as évjáratát, amit még MÁJUSBAN kedvezményes áron tudsz beszerezni a webshopunkban vagy a Laposa Birtokon! http://www.bazaltbor.hu/hu/bor/laposa_balatonbor \#laposabirtok \#laposa \#tobbmintbor \#morethanwine \#laposabirtok \#badacsony \#balaton \#wine \#winetasting \#wineoclock \#estatewine \#local \#supportlocal \#drinklocal \#winedivine \#winelover \#vino \#laposagasztrobirtok

(2) In rain and sunshine. The best anytimewine. http://sauska.hu/en/wines/ furmint-2017 \#sauskawines \#sauskafurmint \#wineofthemoment \#tokaj

(3) Nyáron vöröset? Ne félj tőle! /// Having some red in summertime? Don’t be afraid of that! \#repost @drinkinmoderation and @natashamaryburdett \#redwine \#red \#wine \#bor \#nyár

\#summertime \#summer \#mutimitiszol \#drinking \#cheers \#egészségedre \#sexywine \#mik \#ikozosseg \#magyarbor \#hungarianwine

As online marketing tips usually deal with it a lot, the analysis also examined text length. The longest caption was English-Hungarian bilingual including links (1,251 characters), while the shortest one comprised only four hashtags (54 characters; see Example 4). The most hashtags (26) were added to an invitation message of 598 characters (Example 5). Photos are posted with 11 hashtags on average, which corresponds to the number recommended for the best reach (cf. Cohen, 2015).

(4) \#FRÖCCSLEGÉNYEK \#mikloscsabi \#svabypeti \#szeremleylaci

(5) Kristinus Picnic is reloaded on 18 August. Come and chill with us whilst drinking our award winning wines eating delicious bites and listening to relaxing music. And bring your dog too! Find more details at the link in bio. \#vineyardpicnic \#picnic \#picnictime \#daywithfriends \#livemusic \#outdoorprogram \#barbequeparty \#letsgettogether \#winelovers \#letsgooutside \#winetime \#hungarianwine \#doglovers \#dogprogram \#enjoythenature \#grillparty \#vineyardvines \#vineyardlife \#vineyardvibes 
\#hungarianwinery \#hungariancountryside \#viticulture \#winery \#wineestate \#visithungary \#lakebalaton

The potential of consistency and branded hashtags is exploited by almost every winery (examples 6-7). Most typically, hashtags relate to the topic (e.g.: \#wine \#tour \#tasting \#egribikaver \#áldás \#blessing \#egerwine \#egerwineregion \#coolclimate \#volcanic \#hungary \#winesofhungary \#hungarianwine \#premiumwine \#cuvee \#whitewine \#whitecuvee \#wineoclock \#wineofinstagram \#freshwine \#sauvignonblanc). Less often they relate to a community or only want to garner likes (\#mik \#ikozosseg \#mik_gasztro \#mutimitiszol), and the least frequent ones are unique, stylistically sophisticated hashtags that relate to the context (e.g. \#kilehetettbírni \#summerishere \#bacskiskunboldoggatesz \#igyáljóbort).

(6) We have launched the new vintage of the Egri Csillag white wine! The 2018 Egri Csillag officially available from now \#egricsillag \#launch \#new \#vintage \#2018 \#standrea \#napbor \#sunwine \#eger \#egerwine \#egerwineregion \#letstasteeger \#whitewine \#blendedwine \#wine \#volcanic \#march15 \#celebration \#national \#holiday \#winemaker \#lorinczgyorgy

(7) Szezonkezdet \& Season opening \& \#skoda \#skodakodiaq \#mikloscsabi \#welovemór \#miklóscsabipincéje \#miklóscsabi \#mór \#welovemór \#moriborvidek \#szponzoralttartalom \#reklam \#skoda \#skodakodiaq

\section{The (Assumed) Intention of Content Marketing}

Conscious content marketing intends to contribute in some way to the wellbeing of the audience by, for example, providing help in solving a problem (e.g. through education material), improving the lives or environment of the users (e.g. through propagating a healthy lifestyle), or by sheer entertainment. The imagetext combinations were also examined from these points of view. The category "educational material" was attributed to posts that provided information on the production or characteristics of wine (11 instances were found; see Example 8). The second category was not represented in the corpus. The third category, entertainment, was assigned to posts that apparently intended to be funny and cheer up users (9 instances were found; see Example 9, with video). The three main categories had to be complemented by four others after the examination of the posts. Most of the posts were informative (35): medals awarded to the winery, beginning of harvest season, debut of a new wine, participation in an event (examples 10-11). In 22 posts, the image-text combinations only emphasized the beauty of the landscape, grapes, or wine (Example 12). In 18 instances, the posts were clearly express or implied advertisements (examples 13-14). In the case of five Instagram posts, the poster's intention was unclear. 
(8) Kristinus Euphoria 2016 - Our new blend combines the finest characteristics of Cabernet Sauvignon, Merlot and Blaufränkisch aged in barrique and amphora. \#cuvee \#cuveewine \#redwinelover \#redwineday \#redwinetime \#merlot \#cabernetsauvignon \#blaufränkisch \#barrique \#barriquewine \#amphorawine \#qualitywine \#hungarianwine \#wineblend \#winelabel \#labeldesign

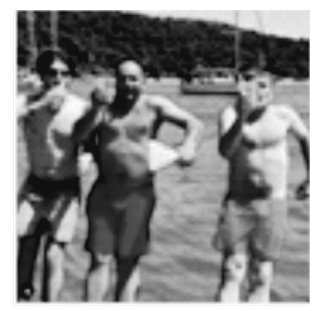
\#uniquetaste \#uniquewine

(9) \#FRÖCCSLEGÉNYEK \#mikloscsabi \#svabypeti \#szeremleylaci

(10) Koch Csaba Balatonfüreden \#kochcsaba \#kochboraszat \#kochwinery \#kochbor \#kochpincészet \#winetasting \#borkostolo \#balatonfured \#halesborunnep \#balaton \#winemaker \#borászok

(11) Nagy örömmel osztjuk meg veletek a hírt, hogy a 2019. évi Országos Borversenyen 900 beküldött minta közül 2016-os Szekszárdi "Faluhely" QV borunkat nagy aranyéremmel, 2016-os Szekszárdi Cabernet Franc "Faluhely", valamint a Gurovica-dúlőből származó Kékfrankos és Merlot Válogatás borunkat aranyéremmel

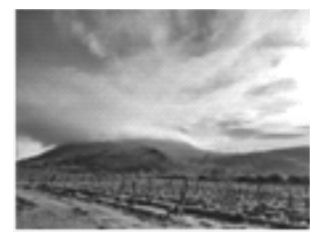
díjazták. Köszönjük! \#bodri \#bodripinceszet \#orszagosborverseny

(12) Nagy-Eged-hegy - Simply amazing \#nagyegedhegy \#grandcru \#vineyard \#hill \#morning \#beautiful \#sunrise \#amazing \#view \#spring \#eger \#egerwine \#egerwineregion \#standrea \#standreawinery \#wonderful \#nature \#hungary \#clouds \#winedestinations

(13) Kristinus Gastro Bistro offers you a special Whitsun menu on Sunday and Monday. Beef consommé with coriander. Lamb shank stew, rosemary polenta, roasted pepper and browned onion jus. Cottage-cheese mousse, Krisecco espuma and vanilla flavored strawberry sorbet. Price: 6.990 HUF Booking: +36 85539 014. \#whitsun \#whitsunday \#whitsundaymonday \#whitmonday \#winedinner \#finedining \#gastrolovers \#gastrolovers \#vineyardlife \#gastrobistro \#gastrolovers \#gastronogram \#finedining \#cheflife \#chefstalk \#artonaplate \#gastropost \#gastrolove \#gastronomylover \#qualityfood \#qualitytime \#colourfulplate \#masterpiece \#yummyfood \#whitewinelovers

(14) Szezonkezdet ¿. Season opening \&. \#skoda \#skodakodiaq \#mikloscsabi \#welovemór \#miklóscsabipincéje \#miklóscsabi \#mór \#welovemór \#moriborvidek \#szponzoralttartalom \#reklam \#skoda \#skodakodiaq

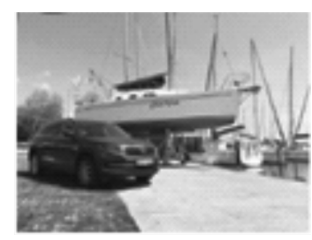




\section{Visual and Verbal Storytelling}

The system of criteria used in this study (whether the photo is eye-catching, easyto-remember, emotionally touching, more than the optical repetition of the text, or reflective of something more than what is evident) could not be expressed in numbers. The authors of the examined contents predominantly failed to exploit the potential in storytelling, but there were some good examples (examples 15-17). (15) In order to fully immerse the complexity of a Tokaj Aszú, scenery is instrumental. Even more so when it comes to the thick, beautifully slowly and lazily-dripping Aszú Essencia. The Onyx-team serves our wine in a white porcelain spoon, displaying its amber-honey complexity and decadently rich nose, patiently waiting for the moment to meet the duck liver mousse on your palate. Slow food at its best, isn't it? \#madeinhungary \#onyx \#herendporcelain \#sauska \#sauskatokaj

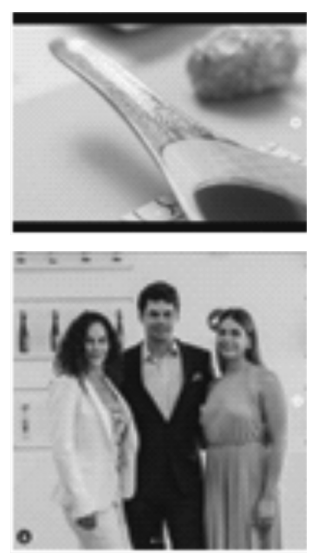

(16) Elérkezett a pillanat, amiért éveken keresztül dolgoztunk: egy új fejezetet nyitottunk az 1883 óta fennálló Hableány történetében! Találkozzunk Badacsony szívében, szeretettel várunk borászati központunkban! + @ hableany_badacsony $q$

(17) Get insight to @csajszombat \#girlsparty at Kristinus Wine Estate. @szabojucus.5hozzavalo and ladies made \#fruitydeserts and learned how to do \#gastrostyling from @gasztro_pr. Then, they made their own personalized \#diy \#spicegarden with @bazsalikomoskert and @ pandarteblog . Besides the gastro related programs, \#fashionandstyle naturally played an important role. @maccosmetics provided the perfect \#makeupand @ artzmodellhungary styled them for the portrait shooting of @pureandpastelphotography \% Photos: @stories_by_ nea. \#wineestate \#eventspace \#uniquestyle \#gastroaddict \#fashionaddict \#girlday \#girlsjustwannahavefun \#summerishere \#weekendevent \#weekendplans \#letsfun \#funtogether \#diyworkshop \#makeupworkshop \#gastroworkshop \#photoworkshop

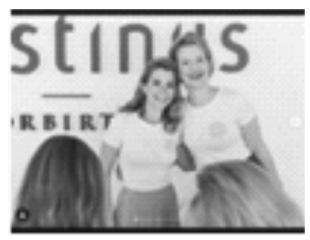




\section{Conclusions}

To obtain the loyalty of users, companies need a well-considered communication strategy tailored to the target audience. However, a lot more than this is required for selling products. The most relevant social media principles are the following: long-term strategy, careful planning, conscious implementation, thorough information about and respect for the potential target audience, and content which is valuable and interesting for the target group and has real impact on its behaviour. The product is also easier to sell if it is attractive and easy to identify with; but wines evidently meet this requirement if offered for the right target audience.

As for content types, there are indeed informative posts that are useful, beautiful posts that are aesthetically pleasing, and clear instances of explicit advertising among the posts of wineries; however, it could evidently enhance user loyalty if posts had more added value. The methodology of storytelling could be effectively used in wine communication for the following types of content: 1. advice and education: providing background knowledge, a look "behind the scenes" (grape varieties, winemaking, viticulture, culinary, design, wine-food pairing) or instructions (cf. "how to" videos on bottle opening or wine serving); 2. help to users (information on moderate wine consumption, wine and a healthy lifestyle); 3. entertainment (people behind the bottle; family and historical stories; wine legends, anecdotes, etc.). In addition, the importance of the personal feeling cannot be overemphasized in wine communication which is specializing in handling uncertainty: winemakers can act as special influencers in their field not only when selling wine (which is, of course, very important) but also in social media marketing.

In view of the above, there is another potential benefit of effective and conscious wine communication: the likes of active, regular, non-ad-clicking visitors are particularly valuable. Likes have become a new standard of value.

The remediation of social relations that has accompanied the rise of consumer culture has effectively managed to transform the nature of affect, from something private, or at least located in small interaction systems, to something that acquires an objective existence as a value creating 'substance' in the public domain. Social media have taken this process one step further. (Arvidsson, 2011) 


\section{References}

Allhoff, F. (ed.). (2008). Wine \& Philosophy. A Symposium on Thinking and Drinking. Malden, MA: Blackwell.

Arvidsson, A. (2011). General Sentiment. How Value and Affect Converge in the Information Economy. <https://ssrn.com/abstract=1815031> (Accessed on: 9 May 2017).

Balázs, G. (2018a). A magyar bor múvelődéstörténetéről [On the Cultural History of Wine]. In: Veszelszki, Á. (ed.), Borkommunikáció. Aszútól a zenitig [Wine Communication. From Aszú to Zenit]. Budapest: Századvég, 20-29.

(2018b). A bor frazeológiája [Phraseology of Wine]. In: Veszelszki, Á. (ed.), Borkommunikáció. Aszútól a zenitig [Wine Communication. From Aszú to Zenit]. Budapest: Századvég, 250-257.

Baldoni, J. (2011). Using Stories to Persuade. Harvard Business Review, 24 March 2011. <https://hbr.org/2011/03/using-stories-as-a-tool-of-per> (accessed on: 9 May 2017).

Balogh, J. (2018). Bor - online [Wine - Online]. In: Veszelszki, Á. (ed.), Borkommunikáció. Aszútól a zenitig [Wine Communication. From Aszú to Zenit]. Budapest: Századvég, 210-219.

Beer, D. (2009). Power through the Algorithm? Participatory Web Cultures and the Technological Unconscious. New Media \& Society 11(6): 985-1002.

Benyák, Z. (2018). Borvidékek kommunikációja [Communication of Wine Regions]. In: Veszelszki, Á. (ed.), Borkommunikáció. Aszútól a zenitig [Wine Communication. From Aszú to Zenit]. Budapest: Századvég, 62-77.

Bergstrom, B. (2008). Essentials of Visual Communication. Laurence King Publishing.

boyd, d. (2010). Social Network Sites as Networked Publics: Affordances, Dynamics, and Implications. In: Papacharissi, Z. (ed.), Networked Self. Identity, Community, and Culture on Social Network Sites. New York: Routledge, 39-58.

Cahill, L.-Haier, R. J.-Fallon, J.-Alkire, M. T.-Tang, Ch.-Keator, D.-Wu, J.Mcgaugh, J. L. (1996). Neurobiology Amygdala Activity at Encoding Correlated with Long-Term, Free Recall of Emotional Information. Proceedings of the National Academy of Sciences of the United States of America (PNAS) 93: 8016-8021.

Cohen, D. (2015). SurePayroll: Infographic: Hashing Out Hashtags. 23 April 2015 <http://www.adweek.com/socialtimes/infographic-surepayroll-hashtags/ 619169> (accessed on: 9 May 2017).

Cormode, G.-Krishnamurthy, B. (2008). Key Differences between Web 1.0 and Web 2.0. First Monday 13(6): 2 June 2008. <http://firstmonday.org/ojs/index. $\mathrm{php} / \mathrm{fm} /$ article/view/2125/1972> (accessed on: 9 May 2017). 
Crosby, L. (2017). How Effective Is Social Media Marketing at Driving Brand Loyalty? AMA 4 April 2017 <https://www.ama.org/publications/ MarketingNews/Pages/how-measure-social-media-brand-loyalty-driver.aspx> (accessed on: 9 May 2017).

Csire, T. (2015). \#selfie. A hashtagek használata az Instagramon [Use of Hashtags on Instagram]. E-nyelv Magazin 2015/2 <http://e-nyelvmagazin.hu/2015/05/29/ selfie-a-hashtagek-hasznalata-az-instagramon/> (accessed on: 9 August 2019).

Gallo, C. (2016). The Storyteller's Secret: From TED-Speakers to Business Legends. Why Some Ideas Catch on and Others Don't. St. Martin's Press.

Gerlitz, C.-Helmond, A. (2013). The Like Economy: Social Buttons and the DataIntensive Web. New Media \& Society 15(8): 1348-1365.

Giulani, L. (2006). Macht und Ohnmacht der Bilder: Eine frisch gewaschene Schürze und die gemordeten Mamelucken. In: Maar, Ch.-Burda, H. (eds.), Iconic Worlds: Neue Bilderwelten und Wissensräume. Cologne: DuMont, 185204.

Gyanó, Sz. (2018). Bor és néprajz. Néprajzi jellegzetességek, eltérések és azonosságok a Balaton két partján [Wine and Ethnography. Ethnographic Peculiarities, Differences, and Similarities on the Two Shores of Lake Balaton]. In: Veszelszki, Á. (ed.), Borkommunikáció. Aszútól a zenitig [Wine Communication. From Aszú to Zenit]. Budapest: Századvég, 78-93.

Hendricks, V. F.-Vestergaard, M. (2019). The Attention Economy. In: Hendricks, V. F.-Vestergaard, M. (eds.), Reality Lost. Markets of Attention, Misinformation and Manipulation. Springer, 1-17.

Hofmeister-Tóth, Á.-Totth, G. (2018). Marketingkommunikáció a borágazatban [Marketing Communication in Oenology]. In: Veszelszki, Á. (ed.), Borkommunikáció. Aszútól a zenitig [Wine Communication. From Aszú to Zenit]. Budapest: Századvég, 108-123.

Howell, Ch. (2013). Is Social Media an Effective Way of Creating Brand Loyalty in Fashion? <https://charlottehowell.wordpress.com/2013/06/24/using-socialmedia-to-form-a-self-image/> (accessed on: 9 May 2017; not available).

Ipacs, G. (2018). Bor és dizájn. Jó bornak nem kell cégér - ja, de! [Wine and Design. Good Wines Do Not Need a Signboard - They Actually Do!]. In: Veszelszki, Á. (ed.), Borkommunikáció. Aszútól a zenitig [Wine Communication. From Aszú to Zenit]. Budapest: Századvég, 138-161.

Jenkins, H.-Clinton, K.-Purushotma, R.-Robinson, A. J.-Weigel, M. (2006). Confronting the Challenges of Participatory Culture: Media Education for the $21^{\text {st }}$ Century. MacArthur Foundation.

Jurgenson, N. (2019). The Social Photo: On Photography and Social Media. Verso. Kemp, E.-Childers, C. Y.-Williams, K. H. (2012). Place Branding: Creating Self-Brand Connections and Brand Advocacy. Journal of Product $\&$ Brand Management 21(7): 508-515. 
Kovács, Lajos. (2018). Bor és szakralitás [Wine and Sacrality]. In: Veszelszki, Á. (ed.), Borkommunikáció. Aszútól a zenitig [Wine Communication. From Aszú to Zenit]. Budapest: Századvég, 30-43.

Kovács, László. (2018). Bormárkanevek [Wine Brand Names]. In: Veszelszki, Á. (ed.), Borkommunikáció. Aszútól a zenitig [Wine Communication. From Aszú to Zenit]. Budapest: Századvég, 124-137.

Lakits, E.-Rácz, D.-Szabadi, D. (2018). Borleírások a gyakorlatban [Wine Descriptions in Practice]. In: Veszelszki, Á. (ed.), Borkommunikáció. Aszútól a zenitig [Wine Communication. From Aszú to Zenit]. Budapest: Századvég, $220-231$.

Lehrer, A. (2009). Wine \& Conversation. Second edition. Oxford: Oxford University Press.

Libert, K.-Tynski, K. (2013). Research: The Emotions That Make Marketing Campaigns Go Viral. Harvard Business Review 24 October $2013<$ https://hbr. org/2013/10/research-the-emotions-that-make-marketing-campaigns-go-viral> (accessed on: 9 August 2019).

Maar, Ch. (2006). Iconic Worlds: Bilderwelten nach dem iconic turn. In: Maar, Ch.-Burda, H. (eds.), Iconic Worlds: Neue Bilderwelten und Wissensräume. Cologne: DuMont, 11-14.

Magyari, S. (2018. A bor nyelvi képe [Linguistic Image of Wine]. In: Veszelszki, Á. (ed.), Borkommunikáció. Aszútól a zenitig [Wine Communication. From Aszú to Zenit]. Budapest: Századvég, 242-249.

Maker, M. H. (2015). Storytelling Is the New Marketing: Five Lessons for Wine Brands Shifting Toward Narrative <http://www.nomacorc.com/blog/2015/02/ storytelling-is-the-new-wine-marketing-five-lessons-wine-brands-shiftingtoward-narrative/> (accessed on: 9 August 2019).

Marwick, A. (2015). You May Know Me from YouTube: (Micro-)Celebrity in Social Media. In: Marshall, P. D.-Redmond, S. (eds.), A Companion to Celebrity. Chichester: Wiley Blackwell, 353-371.

Marwick, A.-boyd, d. (2010). I Tweet Honestly, I Tweet Passionately. Twitter Users, Context Collapse and the Imagined Audience. New Media and Society $<$ http://journals.sagepub.com/doi/abs/10.1177/1461444810365313?journalCo $\mathrm{de}=$ nmsa $>$ (accessed on: 9 August 2019).

Németh, Á. (2018). Nyomdafestéket tûrő ital, avagy néhány alapvetés a borszakírás kapcsán [Essentials of Wine Journalism]. In: Veszelszki, Á. (ed.), Borkommunikáció. Aszútól a zenitig [Wine Communication. From Aszú to Zenit]. Budapest: Századvég, 160-171.

Orbán, G. (2018). A Balaton Bor marketingstratégiája [The Marketing Strategy of BalatonBor]. In: Veszelszki, Á. (ed.), Borkommunikáció. Aszútól a zenitig [Wine Communication. From Aszú to Zenit]. Budapest: Századvég, 196-209. 
Pál, D. L. (2018). Egy pohár bor, egy pohár irodalom [One Glass of Wine, One Glass of Literature]. In: Veszelszki, Á. (ed.), Borkommunikáció. Aszútól a zenitig [Wine Communication. From Aszú to Zenit]. Budapest: Századvég, 188-192.

Pellicer, S. (2018). Influencer vs Brand Ambassador vs Brand Advocate. Medium 16 January $2018<\mathrm{https} / /$ medium.com/@digitaluxe/influencer-vs-brandambassador-vs-brand-advocate-7c278d72700d> (accessed on: 9 August 2019).

Peters, I. (2009). Folksonomies. Indexing and Retrieval in Web 2.0. Berlin: De Gruyter Saur.

Renner, N. (2019). How Social Media Shapes Our Identity. The New Yorker 8 August 2019 [under review] <https://www.newyorker.com/books/underreview/how-social-media-shapes-our-identity> (accessed on: 9 August 2019).

Sammer, P.-Heppel, U. (2015). Visual Storytelling. Visuelles Erzählen in PR \& Marketing. n.d.: O'Reilly.

Senft, T. M. (2008). Camgirls: Celebrity and Community in the Age of Social Networks. New York: Peter Lang.

Sherman, S.-Tuten, T. (2011). Message on a Bottle: The Wine Label's Influence. International Journal of Wine Business Research 23(3): 221-234.

Simon, F. (2019). The Politics of Digital Intimacy. Medium 10 August $2019<\mathrm{https}$ :// medium.com/viewpoints/the-politics-of-digital-intimacy-2da2f0622088> (accessed on: 22 August 2019).

Slegg, J. (2014). What Marketers Can Learn from These Hashtags Fails. The SEM Post 1 August 2014 <http://www.thesempost.com/marketers-can-learnhashtags-fails/> (accessed on: 22 August 2019).

Szabó, E. (ed.). (2017). Gyengébb? Nem! [Weaker? No!]. Budapest: Corvina.

Szakáli, I. L.-Szám, I. (2018). Hungarikum szőlőfajták - borhungarikumok [Hungaricum Vine Varieties - Wine Hungaricums]. In: Veszelszki, Á. (ed.), Borkommunikáció. Aszútól a zenitig [Wine Communication. From Aszú to Zenit]. Budapest: Századvég, 44-61.

Szappanos, P. (2018). Borgazdaság [Wine Economy]. In: Veszelszki, Á. (ed.), Borkommunikáció. Aszútól a zenitig [Wine Communication. From Aszú to Zenit]. Budapest: Századvég, 94-107.

Turner, J.-Shah, R. (2010). How to Make Money with Social Media: An Insider's Guide on Using New and Emerging Media to Grow Your Business. London: Pearson Education.

Van Pappelendam, L. (2012). Anne Helmond and Carolin Gerlitz Explain the Like Economy. Network Cultures 10 March $2012<$ http://networkcultures. org/unlikeus/2012/03/10/anne-helmond-and-carolin-gerlitz-explain-the-likeeconomy/> (accessed on: 22 August 2019).

Veszelszki, Á. (2016). A hashtag mint új frazeologizmus? [Hashtag as a New Phraseologism?]. In: Bárdosi, V. (ed.), A nyelvi pragmatika kérdései szinkrón és diakrón megközelítésben [Questions of Pragmatics from A Synchronic 
and Diachronic Point of View]. Budapest: Modern Filológiai Társaság-Tinta, 147-158.

(ed.). (2018). Borkommunikáció. Aszútól a zenitig [Wine Communication. From Aszú to Zenit]. Budapest: Századvég.

(2018a). Boretikett: illik, nem illik? [Wine Etiquette]. In: Veszelszki, Á. (ed.), Borkommunikáció. Aszútól a zenitig [Wine Communication. From Aszú to Zenit]. Budapest: Századvég, 172-187.

(2018b). Fröccsterminológia [Terminology of Spritz]. In: Veszelszki, Á. (ed.), Borkommunikáció. Aszútól a zenitig [Wine Communication. From Aszú to Zenit]. Budapest: Századvég, 232-241.

(2018c). Bormémek [Wine Memes]. In: Veszelszki, Á. (ed.), Borkommunikáció. Aszútól a zenitig [Wine Communication. From Aszú to Zenit]. Budapest: Századvég, 258-267.

(2018d). Like Economy. What Is the Economic Value of Likes? Society and Economy 40(3): 417-429.

(2018e). Kit és mire motiválnak a motivációs üzenetek? Az online inspirációs tartalmak kommunikációs szerepe [Who and to What Do Motivational Messages Motivate? The Communicative Role of Online Inspirational Messages]. ME.DOK: Média - Történet - Kommunikáció 23(4): 1-57.

(2019) [i.p.]. Pálinka- és borivóknak való [For Drinkers of Wine and Pálinka].

Walter, E.-Gioglio, J. (2015). The Power of Visual Storytelling: How to Use Visuals, Videos, and Social Media to Market Your Brand. New York et al.: McGraw Hill. $\mathrm{W} 1=<\mathrm{http}: / /$ tartalommarketing.hu/mi-az-a-tartalommarketing/> (accessed on: 9 May 2017).

W2 = What Is Content Marketing? <http://contentmarketinginstitute.com/whatis-content-marketing/> (accessed on: 9 May 2017).

$\mathrm{W} 3=<\mathrm{https}: / /$ thepreviewapp.com/7-types-instagram-grid-layouts-plannertips/> (accessed on: 9 August 2019).

$\mathrm{W} 4=<$ https://turizmus.com/szallashely-vendeglatas/magyar-bor-szemelyesenime-az-uj-magyar-borarculat-1162540> (accessed on: 9 August 2019). 